\title{
5. NORTHWEST PACIFIC BASALTIC BASEMENT: DSDP SITE 197
}

\author{
The Shipboard Scientific Party ${ }^{1}$
}

\section{SITE DATA}

Occupied: $3-8$ Oct. 1971

Position: Abyssal floor east of the Izu-Bonin Trench; lat $30^{\circ} 17.4^{\prime} \mathrm{N}$

long $147^{\circ} 40.5^{\prime} \mathrm{E}$

Water Depth: 6143 meters

Number of Cores: 1

Total Penetration: 278 meters

Deepest Unit Recovered: Basalt

Main Results: The subbottom topographic high on which Site 197 was drilled is volcanic in composition. The basalt either was emplaced when the underlying crust was formed or during a later volcanic eruption. The overlying sediments were not sampled because of a stuck string and, consequently, the age of the basalt is unknown.

\section{BACKGROUND}

The seismic reflection record obtained by Dr. T. A. Davies on ARIES VII indicated a possible basement high some 30 miles west of Site 196. It was decided to drill on this high in order to pursue the older sediments and possibly basement, where total depths and penetration might not be so great. With the samples and experience of Site 196, we planned to drill several hundred meters until drilling conditions suggested that coring was appropriate and that we did not have to sample the upper layer in the hope of maintaining better hole conditions.

Nearly half of the working time of the leg was over at this point. It was apparent that Hole 197 would be our last chance to sample the oldest sediments and basement in the area of the western Pacific considered by most workers as the place most likely to possess the longest geological record in the deep Pacific. Location and bathymetry of Site 197 are shown in Figures 1 and 2, respectively, and the Glomar Challenger seismic profile across the site is shown in Figure 3.

\footnotetext{
${ }^{1}$ Bruce C. Heezen, Lamont-Doherty Geological Observatory; Ian D. MacGregor, University of California, Davis; Helen P. Foreman, Oberlin College; George Forristall, Eidgenössische Technische Hochschule, Zürich; H. Hekel, Queensland Geological Survey, Brisbane; Reinhard Hesse, Technische Hochschule, Munich; Robert H. Hoskins, New Zealand Geological Survey, Lower Hutt; E. John W. Jones, University College, London; Ansis Kaneps, Scripps Institution of Oceanography, La Jolla; Valeri A. Krasheninnikov, Academy of Sciences, Moscow; Hakuyu Okada, Kagoshima University, Japan; Michael H. Ruef, Washington Department of Ecology, Olympia.
}

\section{OPERATIONS}

The site was staked at 0620 on 3 October 1971 when the beacon was dropped while underway (course, $262^{\circ}$ ). A few miles east of the site, two small 150-meter-high knolls were crossed which gave strong side echoes on the profiler and fuzzy bottom echoes on the echo sounder. One was flanked by a scour moat 40 meters deep which resulted in a similar thinning in the upper transparent layer. The opaque layer seemed somewhat thinner at Site 197 than at Site 196. However, the rise and convergence of deeper reflectors seen on the ARIES VII record were not observed on the Glomar Challenger record on approaching Site 197 from 196 along a course nearly identical to the ARIES VII track. However, the fuzzy echoes, the steep slopes, and the presence of the scour moat suggested that the knolls represented rock outcrops and seemed to confirm the basement high indicated in more detail on the ARIES VII record. At 2200 on 3 October, bottom was sensed by the weight indicator at 6150 meters. The nearly identical PDR depth of 6153 was adopted as mud line $(3244$ tau $=6137+$ $16=6153$ meters). The center bit was dropped and at 2230 on 3 October, Hole 197 was spudded in. At 2353 on 3 October drilling resistance indicated that the top of the opaque layer had been reached at 6247 meters or 94 meters below mud line. Drilling then proceeded at a fairly steady rate. Then, at 1030 on 4 October, after spending over 50 minutes drilling the previous 9 meters, it was decided to core. The drilling record is given in Figure 4.

Core 1 ( 6428 to 6436 meters, see Table 1) was cut from $1030-1200$ on 4 October and consisted of basalt with calcite veins. The diameter of the core was only about 1.5 inches, suggesting that the cones were bent in. Thus, the bit was badly worn. In retrieving the core barrel, the string stuck in the hole. After 5 hours of alternate pulling and slacking off and pumping 300 barrels of oil and 200 barrels of lube oil, rigging of the electrical shooting cable began at 2000 on 4 October. The plan was to shoot off at the lowermost of the upper two bumper subs. The logging winch had not been used for some time and the counter would not work. After the counter was repaired the brake would not function, so the charge was lowered slowly under power. Halfway down the hydraulic lines began to fail, and several hours were required to replace them. On lowering to the bottom, the charge failed to detonate, so it was retrieved at 1200 on 5 October. From 1200-1630 a new charge was lowered with a percussion detonator on the sand line. It too failed to detonate and was retrieved, inspected, and a new charge was sent back (from $1630-0100$ on 6 October) on the mud line. The percussion detonator failed to operate a second time. After communication with shore, it was decided to try to twist off, and 480 feet of pipe was added to the string. From $0100-2130$ on 6 October the ship was sent in 


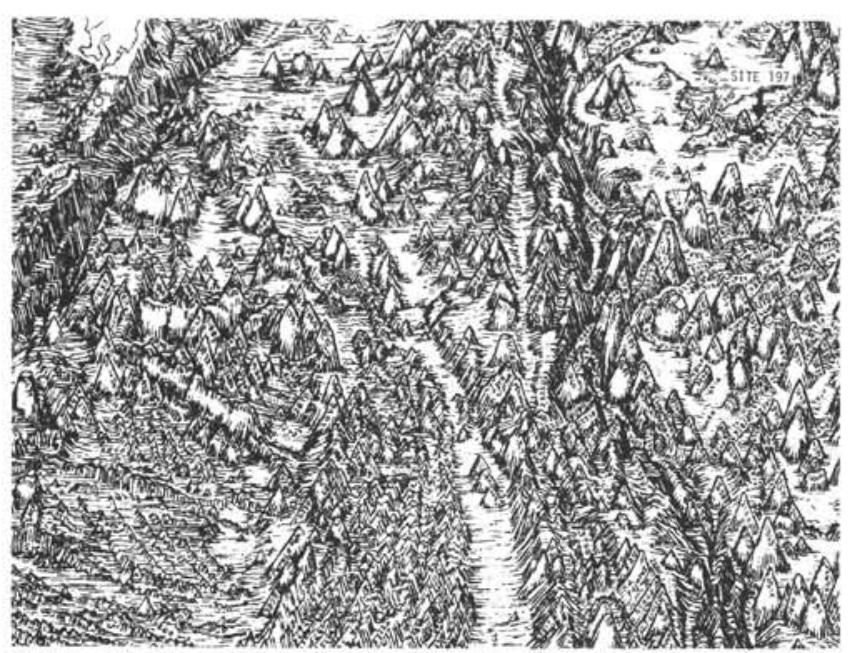

Figure 1. Location of Site 197.

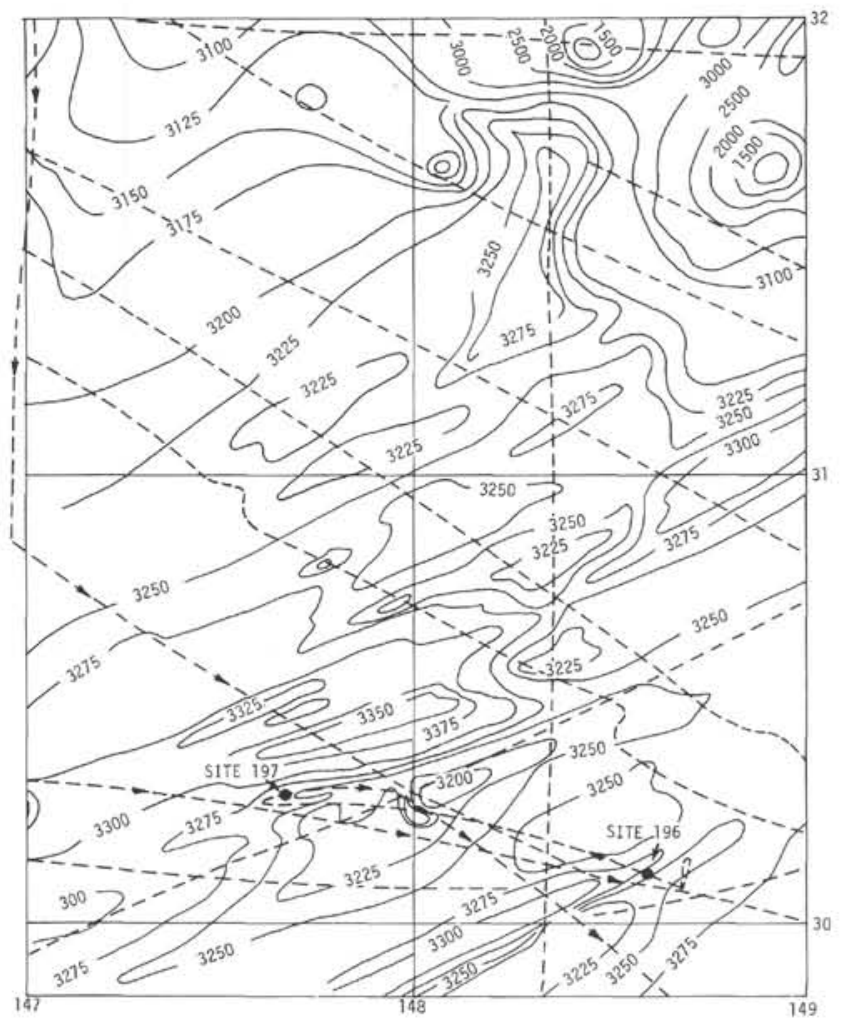

Figure 2. Bathymetry in the vicinity of Site 197 (based on various sounding lines). Contour interval 100 tau (1 tau $=1 / 400$ sec .).

several-hundred-meter excursions by use of the thrusters. After over 20 hours of this treatment, it was decided to rig the percussion detonator again (2130-0100 on 7 October). The third attempt in firing the percussion detonator ended in failure. While preparing to lower the shooting cable, it was found that the pipe would rotate, so 50 barrels of mud were sent down to try to clear the hole. After the mud, the drillers pumped a quantity of fresh water through the hole on the offhand chance that the sticking formation might be rock salt. It was the opinion of several men aboard that

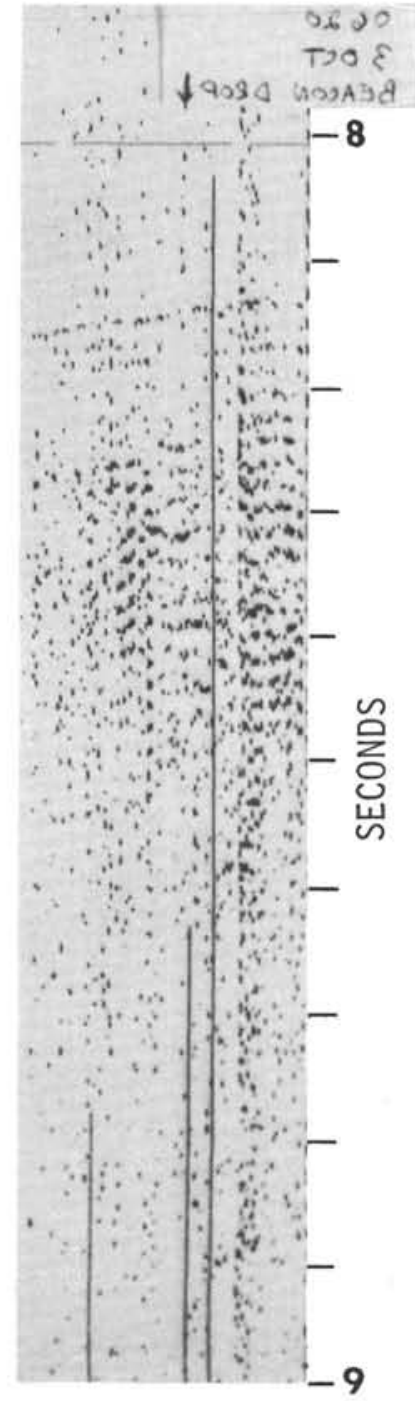

Figure 3. Seismic profile across Site 197 on site approach.

sufficient current to set off the electrical firing detonator could reach the detonator if all the leads in the logging cable were used and the collar locator removed from the assembly. These modifications were made, and the electrically detonated charge was lowered on the logging cable at 0100 on 7 October and the pipe blown off at the mud line at 0600 . The shot-off pipe came aboard at 2230 the same day. The wire was spooled off the sand line, the rig floor secured, and the ship got under way for Site 198 at 0203 on 8 October. Two days and 16 hours were lost trying to shoot off the stuck pipe, but the final success in shooting off had avoided a worse fate, for there was insufficient pipe aboard to make up a new string and thus, the prospects were a dead run to Hawaii and Fiji if the string had been lost and the planned schedule was to be followed.

\section{LITHOLOGY}

The single core (Core 1; 273 to 283 meters; 1 meter recovered) is composed of a fine-grained tholeiitic basalt. Examination of the drilling rates as a function of depth indicates an upper transparent layer, presumably of silty 


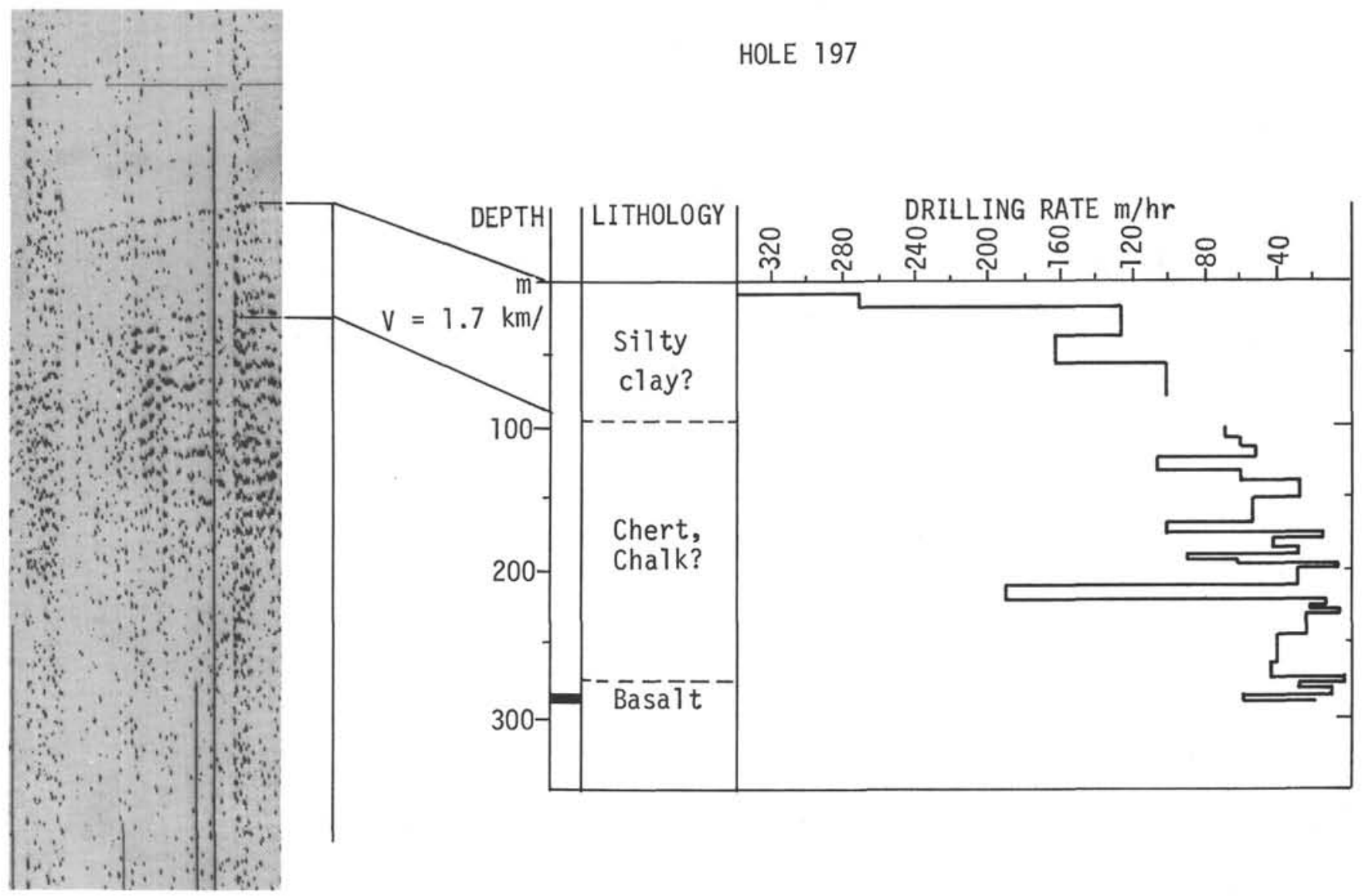

Figure 4. Correlation of drilled record at Site 197 with seismic profile.

clays, approximately 103 meters thick, underlain by approximately 163 meters of a chert/chalk/limestone sequence.

The recovered sample is composed of a fragmented core of a fine-grained tholeiitic basalt which is made up of plagioclase, augitic pyroxene, opaque iron oxides, and a serpentine-like alteration product. The basalt is cut by many veinlets (up to $0.5 \mathrm{~cm}$ ) of calcite bordered by a thin margin of a greenish mineral. In one section $(20$ to $22 \mathrm{~cm})$ intense veining results in complete alteration of the enclosed basalt, although in general the vein boundaries are sharp, and little or no alteration extends into the basalt.

Modal proportions which vary slightly are as follows: plagioclase, $50 \%$ to $60 \%$; augite, $40 \%$ to $50 \%$; iron oxides, $2 \%$ to $5 \%$; serpentine-like alteration, $1 \%$ to $10 \%$. Plagioclase occurs as tabular to acicular crystals which are often skeletal or hollow and filled with a fine-grained basaltic matrix. Plagioclase varies in composition from $\mathrm{An}_{60}$ to $\mathrm{An}_{66}$ with many grains having more sodic margins down to approximately $\mathrm{An}_{25}$. In the coarser-grained fractions augitic pyroxene occurs as granular grains, but is found as tiny $(<0.5 \mu \mathrm{m})$ grains in feathery and radiating clusters with plagioclase in the fine-grained samples. The opaque phases are scattered through the rocks as subhedral to skeletal crystals or as fine dusty specks. In one case the serpentine-like alteration product occurs as a pseudomorph after a single xenocryst of olivine, but more typically it is more greenish in color and fills occasional vesicles, or is interstitial to the plagioclase and pyroxene. Only a few olivine xenocrysts were seen in one section ( 82 to $14 \mathrm{~cm}$ ); these are now completely altered to serpentine.

Linear variations along the core are minor. In the top and bottom $10 \mathrm{~cm}$ the grain sizes are distinctly finer (plagioclase, 2 by $10 \mu \mathrm{m}$; augite, $4 \mu \mathrm{m}$ ) compared with the

TABLE 1

Coring Summary, Site 197

\begin{tabular}{|c|c|c|c|c|c|c|c|c|c|c|c|}
\hline \multirow[b]{2}{*}{ Core } & \multirow[b]{2}{*}{ (Sep) } & \multirow[b]{2}{*}{ Time } & \multicolumn{2}{|c|}{$\begin{array}{l}\text { Subbottom } \\
\text { Depth }(\mathrm{m})\end{array}$} & \multicolumn{2}{|c|}{ Total Depth (m) } & \multirow{2}{*}{$\begin{array}{c}\text { Cored } \\
(\mathrm{m})\end{array}$} & \multirow[b]{2}{*}{ Recovered } & \multirow[b]{2}{*}{ Age } & \multirow[b]{2}{*}{ Lithology } & \multirow[b]{2}{*}{ Paleontology } \\
\hline & & & Top & Bottom & Top & Bottom & & & & & \\
\hline 1 & 4 & 1500 & 275.0 & 283.0 & 6428.0 & 6436.0 & 8 & 1 & - & Basalt & - \\
\hline
\end{tabular}

Note: Mud line is at 6153 meters. 
central section of the core (plagioclase, 5 by $300 \mu \mathrm{m}$; augite, 20 to $40 \mu \mathrm{m}$; oxides, $30 \mu \mathrm{m}$ ). Modal proportions vary slightly with plagioclase being slightly greater and augite less in top $20 \mathrm{~cm}$ and bottom $6 \mathrm{~cm}$. The serpentine-like alteration is most abundant in the center of the core from 42 to $82 \mathrm{~cm}$. The textures vary from intersertal through subophitic to diabasic, with intersertal and feathery textures being more representative of the top and bottom $10 \mathrm{~cm}$, while subophitic and diabasic textures are more characteristic of the central portions.

It is not possible to give a definitive answer as to whether this basalt represents basement. However, the absence of glass, the presence of fine-grained margins, and the alternating variation of drilling rates in the bottom 16 meters of the hole would suggest that the recovered basalt may be part of a sill-sediment sequence with the basalt layers varying from 1 to 2 meters thick.

\section{BIOSTRATIGRAPHIC SUMMARY}

The single core recovered from Hole 197 (275-283 meters below the sediment surface) was composed of basalt. The only other recovery was some pebbles from the center bit before Core 1 was cut. Two sandy siltstone pebbles contained only common poorly preserved Radiolaria. No nannofossils or foraminifera were recovered. Among the poorly preserved Radiolaria, only two species were identified: Dictyomitra leptoconica and forms of the Sphaerostylus lanceola group, both present in Hole 196 at a comparable level and known to range upward. However, the absence of Staurosphaera septemporata and common members of the genus Podobursa, common at this level in Hole 196, suggest that these two pebbles were carried down from sediment higher in the core. Core 1 is probably similar in age (Valanginian-early Hauterivian according to nannofossils) as are Cores 3 and 4 of Hole 196 at a comparable level.

Biogenic components found in Site 197 cores are summarized as follows:

\section{Core 1:}

Foraminifera: none.

Nannofossils: none.

Radiolaria: None in situ. Rare, poor Radiolaria in two pebbles from the center bit, similar to those from Cores 196-3 and 4, indicate an Early Cretaceous age.

\section{PHYSICAL PROPERTIES}

Sonic velocity measurements along with GRAPE and water displacement bulk density measurements were made on selected samples of the basalts recovered. The results are presented in Table 2.

TABLE 2

Physical Properties of Individual Samples, Site 197

\begin{tabular}{cccccccc}
\hline & & \multicolumn{2}{c}{ Density } & & \multicolumn{2}{c}{ Sonic Velocity } \\
\cline { 3 - 5 } & & & $\begin{array}{c}\text { Water } \\
\text { Displace- } \\
\text { ment }\end{array}$ & GRAPE & $\begin{array}{c}\text { Parallel } \\
\text { to } \\
\text { Bedding }\end{array}$ & $\begin{array}{c}\text { Perpendic- } \\
\text { ular to } \\
\text { Bedding }\end{array}$ \\
\hline 1 & 6 & Basalt & 2.13 & 2.07 & & 2.79 \\
1 & 10 & Basalt & 2.72 & 2.61 & 5.21 & 5.01 \\
1 & 13 & Basalt & 2.72 & & & 5.12 \\
1 & 16 & Basalt & 2.77 & & & \\
1 & 19 & Basalt & 1.86 & 2.57 & 4.83 & \\
\hline
\end{tabular}

The samples tested showed fairly consistent high velocity and density, except for Sample 6, which was highly altered and had much lower density and velocity. Sample 10 had a slight acoustic orthotropicity. It was impossible to check this trend in the other samples because their internal fracture planes attenuated the signal in at least one direction.

\section{CONCLUSIONS}

Sites 196 and 197 are only about $100 \mathrm{~km}$ apart; the depths of water differ by less than 50 meters, and the drilling rates in the upper 200 meters of each hole are virtually identical. It can be thus inferred that the age of the basalt recovered from 283 meters subbottom at Site 197 is at least as old as the Late Jurassic-Early Cretaceous limestones sampled at Site 196. It seems probable that the basalt represents basement and is original oceanic crust. The ARIES VII seismic reflection profile suggests that Site 197 is on a basement high and this, of course, is the reason the site was selected. Although the possibility of later volcanic events can never be excluded, the results of previous DSDP holes suggest that normally the age of the basal sediment overlying basalt reflects the age of the underlying crust fairly accurately. Thus, if the Late Jurassic-Early Cretaceous limestones of Site 196 can be correlated by the drilling rate curves from Sites 196 to 197 , then the basalt is at least as old as that limestone. The additional thickness of sediments below the total depth at Site 196, inferred from the ARIES VII reflection record, introduces possible uncertainty. Despite several obvious uncertainties, it seems reasonable to conclude on the basis of present data that the oceanic crust of the abyssal Pacific, $1500 \mathrm{~km}$ east of the Bonin Trench, includes Jurassic tholeiitic basalt. 

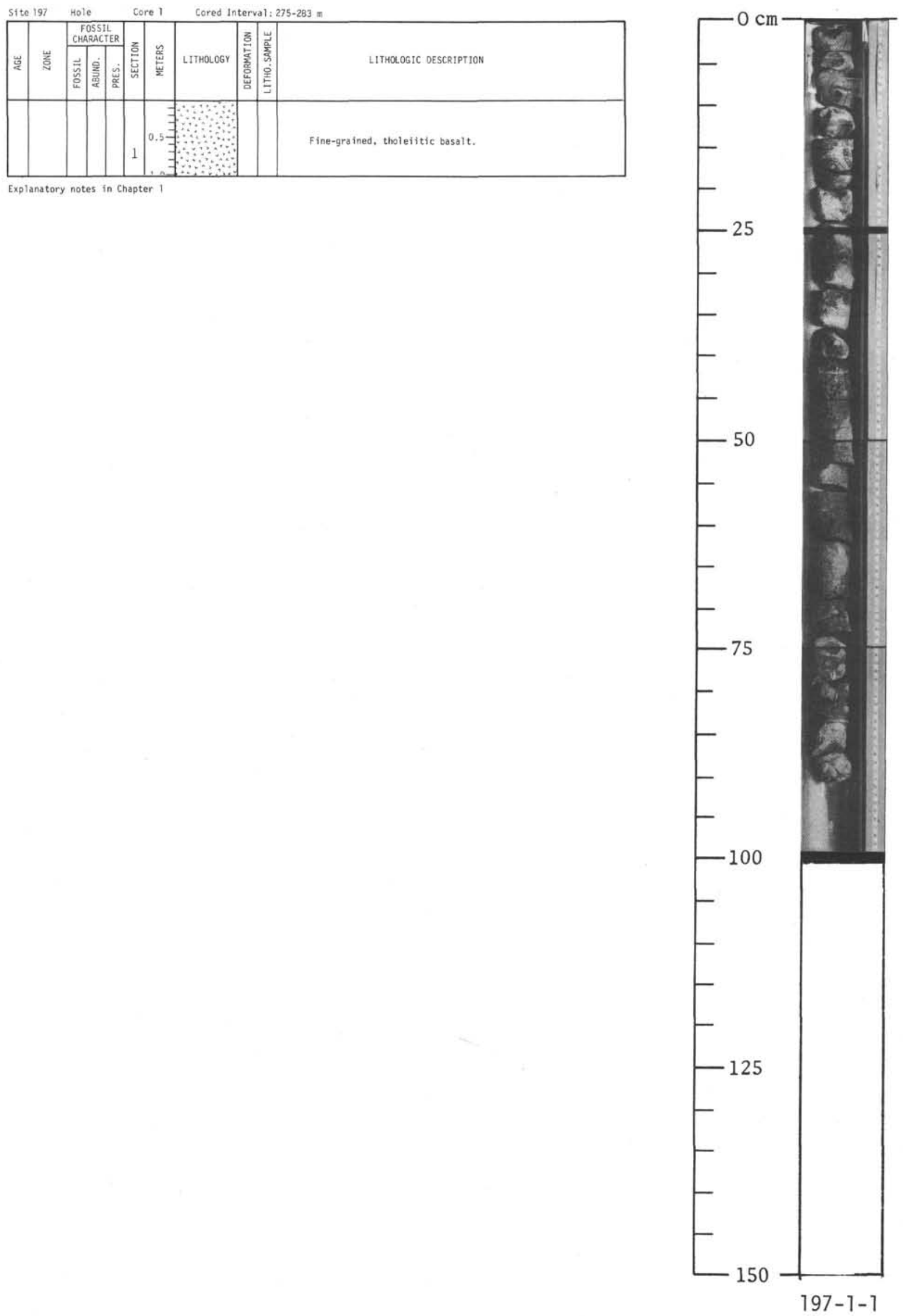